\title{
Sensory Perception: A Comparative Study of Western Psychology and Buddhist Psychology
}

\section{Ven. Gomila Gunalankara Thero ${ }^{1}$}

\begin{abstract}
Sensory Perception (SP) is a fundamental psychological process of species for their survival, as it predominantly involves with memory and learning. In human, therefore, a spectacular system of sensory processing has developed. Every being in the world has special features of their sensory information processing systems. This study focused on exploring the Buddhist Psychological explanation of SP of human beings in comparison to the theories and models of SP in Western Psychology (WP). The study was conducted under qualitative research methods, based on textual studies. Western psychologists have introduced number of theories such as Human Information Processing Theory of Cognitive Psychology through experimental researches to understand the biological and psychological process of SP. Buddhist Psychology (BP) of SP is mainly laid on the explanations in Abhidhamma pitaka and Sutta pițaka. The special attention was, here, paid on Sabbacittasādhārana cetasika and Cittavịthi in the Abhidhamma pitaka and Madupindika sutta in Sutta pitaka. In conclusion, both WP and BP comprise of complex theories and models of SP. The two approaches are less comparable, as there are different complex explanations except certain similarities.
\end{abstract}

Key Words: Sensory Perception, Cognitive Model, Bio-psychological Model, Sabbacittasādhārana Cetasika, Cittavịthi Analysis

\footnotetext{
${ }^{1}$ Department of Practical Buddhist Studies, Bhiksu University of Sri Lanka, Anuradhapura, Sri Lanka, ggunalankara@busl.ac.lk
}

Date Received: $\quad 02^{\text {nd }}$ November 2018

Date Accepted: 14 $4^{\text {th }}$ November 2019 


\section{Introduction}

Sensation and Perception are two parallel topics which are highly discussed in the field of Psychology. In the history of psychology, experimental psychologists, gestalt psychologists and cognitive psychologists have developed significant theories and models on sensation and perception based on scientific researches. The distinction between sensation and perception was developed by Thomas Reid, a Scottish philosopher, in 1765. It is defined, "Sensation is the stimulation of the sense organs and perception is the selection, organization, and interpretation of the sensory input" (Weiten, 2005, p. 91). According to the explanations of biological psychologists, sensation detects stimulations (sensory inputs) from the internal or external environment, with absorption of energy such as light and sound waves through sensory organs such as eye and ear. Thereafter, the information is transduced and transmitted to the brain through the nerves system, so that interprets into meaningful information (perception).

There are numerous theories and models developed by the Western Psychologists through experiments to explain the process of SP. Those theories and models mainly prefer the Biological and Cognitive Process of SP in relation to the functions of sense organs and the brain. Each theory and model in WP fulfills shortages of each other.

Referring to the BP, Abhidhamma pitka includes an enormous analysis on human mental conditions and psychological functions. Especially, Dhammasanganippakarana of Abhidhamma pitaka can be considered as the Buddhist Psychoanalysis. In line with, the Sutta pitaka consist of number of teachings on the psychology of human mind and its process.

\section{Research Problem}

How is the Sensory Perception process analyzed in Buddhist Psychology and is it comparable to the Western Psychological Analysis? 


\section{Objective}

The objective of this research is to compare the psychology of Sensory Perception analyzed in Buddhist Psychology and Western Psychology, referring to the selected theories and models from both streams.

\section{Literature review}

There are number of researches and studies conducted on sensation, perception and information processing in both Western and Buddhist Psychology. The Western Psychological theories and models of SP are very familiar to the field where as Buddhist psychological explanations of which are very rare. Prof. E.R. Sarachchandra in his 'Buddhist Psychology of Perception' (1958) gives a comprehensive study on SP, paying attention on teachings in Sutta pitaka and Abbhidhamma pitaka. Prof. Y. Karunasada provides an explanation on seven fold Universal Mental Concomitants, under the theme of 'Sabbacittasādhärana cetasika of Abhidhamma Psychology' (1995) (translated by A. Thilakeratne). Even though these studies revealed BP of SP, they did not provide a comparative study with WP.

'The Concept of Visual Perception; A Comparative Study of Buddhist and Western Psychology' (2013) is a study conducted by Ven. Aththaragoda Piyadhamma. He, in his study, compares theories of Visual Perception in two systems. Concluding his study, he mentions that WP mainly concerns with biological process of visual perception and Gestalt psychology comes up with a cognitive view of which while BP mainly emphasizes a psychological perspective on visual perception entirely (Piyadhamma, 2013, p. 265).

\section{Methodology}

As this is a comparative review, the study was conducted under the qualitative research methods based on textual studies. Documentary sources of WP and Buddhist teachings and electronic sources such as websites were used as materials for data collection. Findings were discussed and analyzed using the content analysis method. 


\section{Findings}

\section{Western Psychology of Sensory Perception}

Sensation and perception process of humans and other beings has become a major research field among scholars in the WP. Especially, experimental psychologists, gestalt psychologists, cognitive psychologists, biological psychologists, neuropsychologists have conducted scientific researches on this area and have developed number of theories, models and principles explaining the process of SP.

Gestalt psychologists have introduced several principles of SP such as grouping with similarity or proximity, figure-ground relationship, law of continuation, closure and concept of whole etc. These principles explain the forms of vision, how the brain organizes the visual patterns and certain cognitive functions. But these principles are merely to explain the visual perception.

Human Information Processing (HIP) model of Cognitive Psychology is one of the major theories on SP in WP. The HIP model explains what occurs during the stages (attention, perception, short-term memory etc.) of processing information (Reed, 2004, p.03). The HIP model depicts several stages of the process, including Input (information from external or internal environment), Sensory store, Filter, Pattern recognition, Selection, Short Term Memory (STM), Response, and Long Term Memory (LTM).

Collecting and processing information in every second is an active function of all living beings. Primarily, information from external or internal environment receives through the sense organs which is containing short sensory store. "Sensory store provides a short storage of information in its original sensory form. It is a part of the memory that holds analyzed sensory information for a fraction of a second, providing an opportunity for additional analysis following the physical termination of a stimulus. Filter is a part of attention in which some perceptual information is filtered out and not recognized, while other information receives attention and recognized. Pattern recognition is the stage of perception during which a stimulus is identified" (Reed, 2004, p.03). 
Within that process, recognized, perceived and selected information is transmitted into the Short Term Memory (STM) where information holds only about 20-30 seconds. Most important and necessary information is, thereafter, stored in the Long Term Memory (LTM) which has no capacity limits and lasts from minutes to entire lifetime. The information can flow in both directions, within sensory store and LTM. An earlier stage can, therefore, be influenced by information in a later stage, and the other side is also the same (Reed, 2004, p.03).

Bio-psychological model in WP gives a comprehensive explanation on what occurs during the SP process on the basis of biology. It is mainly based on the functions of the nervous system related to the particular sense organ and the process of the brain. According to the bio-psychological explanations, each sensory organ is particularly adapted to detect stimulus from the environment as energies (e.g. light, sound, chemical). There are five sense organs specialized for visual perception, auditory perception, olfactory perception, gustatory perception, somatosensory perception particularly. Sensory receptors in each sensory organ convert the detected stimulus into electrical impulse and transmitted to the particular region of the brain through sensory nerves so that to recognize, organize, interpret and store (the process of perception).

For instance, the eye is specialized to detect light from the external environment. Every moment when the eye is open, light energy enters into the eye passing through the cornea, pupil and the lens, and falls on the retina where the image of the object reflects upside down. Cones and Rods located on the innermost layer of the retina are specialized in daylight vision, colour vision and night vision. The photoreceptors stimulated by the light trigger neural impulse. The visual information converted into a neural impulse travels to the brain through the optic nerve and processes in the visual cortex of the occipital lobe of the brain where the visual input is perceived, analyzed, interpreted and stored etc. The process in the brain is called the perception. As shown in the above example, each SP is based on each biological function. 


\section{Buddhist Psychology of Sensory Perception}

Buddhist psychological explanation on SP is mainly found in the Abhidhamma pitaka and in several discourses of the Sutta pitaka. In the Abhidhamma pitaka, the analysis of Sabbacittasādhārana Cetasika and Cittavịthi are two teachings that are significant in explaining the process SP.

The universal mental states (sabbacittasādhārana cetasika) compiled in the Dhammasanganippakarana and elaborated in the Abhidhammatthasangaha is a very important category of Abhidhamma on information processing. It includes seven mental concomitants, namely; Phassa (Contact/mental impression), Vedanā (Feeling), Sañ̃āa (Perception), Cetanā (Volition), Ekaggatā (one-pointedness/ concentration), Jịvitindriya (Psychic life/ vitality) and Manasikāra (Attention/ advertence). These seven mental concomitants are common to every consciousness (89 or 121 citta-s), with no distinction of both kusala and akusala citta, hence, it is called Sabbacittasādhärana (universal). According to the Abhidhammic analysis, even though these mental concomitants are commonly arisen with every consciousness (citta), they do not run on gradual process and arise simultaneously with a particular citta. The Phassa is described in Abhidhamma as a non-material relationship between the sense organs and their objects (Sarathchandra, 1958, p.28).

However, 'Phassa' is here mentioned as the first factor. The Madupindika sutta in Majjhimanikāya explains clearly how the phassa arises, and what, thereafter, occurs in the process. Considering the eye, for instance, "the visual consciousness (cakkhu viñ̃̃ana) arises because of the eye and material shapes; the meeting of the three is sensory impingement (contact/ phassa); feelings (vedanā) are because of sensory impingement (phassa); what one feels one perceives (sañ̃̄a/ sañjānāti); what one perceives one reasons about (vitakketi); what one reasons about one obsesses (papañceti); what obsesses one is the origin of number of concepts and obsessions (papañcasaññāsankārā samudacaranti) which assail a man in regard to material shapes cognizable by the eye" (Silva, 1979, p 24). According to this explanation there are several stages before the perception; cakkhu viññana, phassa 
and vedanā. After perception, the person reasons about, thinks about and obsesses about the stimulus. That is considered the beginning of number of concepts, ideas, obsessions etc. Mrs. Rhys Davids mentioned in her Buddhist Psychology (1914) "The most notable example of it is important formula of natural causation as exemplified in the process of life being bound up with $d u k k h a . .$. Sense and feeling stirred by sense are converted into motor presentations; as desire, etc. But, we meet with no closer analysis of intellectual process, of what has, in our own psychology being called representative and re-representative cognition or ideation." (Davids, 1914, p. 88). According to her clarification, SP is analyzed in Buddhism as a cognitive process which is causally conditioned and it is, further, connected with the human suffering (dukkha). This Buddhist psychological explanation is somewhat different from the stereotyped theories and models of SP in the WP.

One of the other important explanations on SP is the analysis of Cittavithi (Thought Process) in Abhidhamma pitaka. The duration of one Thought Moment (cittakkhana) consists of three steps; genesis, static and dissolution. One Thought Process includes seventeen Thought Moments. According to the sense doors, six thought processes are analyzed in the Abhidhammatthasangaha, as follows.

1. The thought process connected with the eye-door.

2. The thought process connected with the ear-door.

3. The thought process connected with the nose-door.

4. The thought process connected with the tongue-door.

5. The thought process connected with the body-door.

6. The thought process connected with the mind-door. (Nārada, 1980, p.206)

When an object is presented to the mind-consciousness through one of the five doors (eye-body), a Thought Process runs as follows (Table 01). That is called the pancadwārāwajjana cittavịthi. The thought process connected with mind (manodwārāwajjana cittavịthi) is deferent from it. 


\begin{tabular}{ll}
\hline 17 & Tadālambana (Registering Consciousness) \\
\hline 16 & Tadālambana (Registering Consciousness) \\
15 & Javana (Impression) \\
14 & Javana (Impression) \\
12 & Javana (Impression) \\
11 & Javana (Impression) \\
10 & Javana (Impression) \\
9 & Javana (Impression) \\
8 & Votthapana (Determining Consciousness) \\
7 & Santirana (Investigating Consciousness) \\
6 & Sampaticcana (Receiving Consciousness) \\
5 & Cakku Viññana (eye - One of Five Sense - Consciousness) \\
4 & Pañcadvārāvajjana (Sense-door Consciousness) \\
\hline 3 & Bhavańgupaccheda ( Arrest Bhavańga) \\
2 & Bhavańga Calana (Vibration Bhavańga) \\
1 & Atịta Bhavańga (Past Bhavańga) \\
\hline & $\quad$ (Nārada, 1980, p.34) \\
\hline
\end{tabular}

Table 01. Thought Procedure Connected with Five Doors

According to the table depicts, the thought process connected with eye door (cakkhudvārika atimahanthārammana cittavịthi) runs as follows. "A visible object which has passed one instant enters the avenue of eye. Then, the Bhavańga (1) vibrates for one thought moment and perishes (2), arresting the Bhavańga stream (3). Subsequently, the five-door apprehending consciousness (4) arises and ceases apprehending that very visible object. Thereafter, thought moment of eye consciousness sees the very form (5), of recipient consciousness receives (6) it, of investigating consciousness investigates (7) it and of determining consciousness determines (8) it. Then, one of the twenty nine kinds of sense-sphere Javanas causally conditioned runs for seven thought moments (9-15) and two retentive 
resultants (16-17) arise accordingly. Finally comes the subsidence into the Bhavańga" (Nārada, 1980, Pp. 207-208). Each thought moment is causally conditioned and run in a gradual process. Similarly, different thought processes are illustrated in Abhidhammatthasangaha, according to the sense-door, the kind of person and the plane of existence etc.

\section{Discussion}

According to the $\mathrm{BP}$, human receipts information from the external environment at every moment through five doors; eye, ear, nose, tongue and body (skin). Each of this information meets just mind called viññana (consciousness) at very first and then phassa (contact) arises. In seven fold mental concomitants, phassa is the first mental factor. According to the Madupindika sutta in Majjhimanikāya, consciousness (viñ̃̃ana) arises because of the biological factor (sense organ) and external information. Considering the eye, for instance, the visual consciousness (cakkhu viñ̃anna) arises because of the eye and material shapes. The meeting of these three; sense organ (eg. cakkhu), external information (eg. rupa) and consciousness (eg. cakkhu viñ̃̄anna), is the phassa (contact/ sensory impingement).

In line with, Mahāhatthipadōpama sutta in Majjhimanikāya emphasizes that there should be a healthy sense organ (Ajjhattikam cakkhum aparibhinnam höti) as a basic factor for a complete SP. Here, Ajjhattikam cakkhum means the biological strength of the eye or ability to see. Thus, the BP emphasizes the biological factor as the first of SP process, as shown in the Bio-psychological model in WP. After this basic process, the BP explains deep affective and cognitive processes of SP from feeling (vedanā) to the origin of number of concepts and obsessions (papañcasañ̃āansankāā samudacaranti) which assail a man in regard to information cognizable by the sense organ.

Seventeen thought moments which are causally conditioned in a cittavithi is very complex analysis, as it starts from the very first drop of the point where the information processing is begun, at the vibration of bhavanga citta (inner psychological alert), which cannot be seen in the western psychological 
explanations. For a complete perception of a physical object through any sense door of five, the mind needs to pass seventeen thought moments. The rapidity of the process is as such as number of thought moments geneses and cease within the duration of one millisecond, and then again, a new thought process is taken place.

How-ever, Sense-door Consciousness (eg. cakkhu viññana) which was explained before arises at the fourth and fifth thought moment of the stream of thought process. Before that, another complex inner psychological process on received information comes to pass. The cognitive process is taken place after that and the thought moments of Javana (Impression) play a significant role in processing the perceived information.

\section{Conclusions}

Both WP and BP provide theories, models and principles with complex explanations on SP. Therefore, the two approaches are less comparable, as there are different complex explanations, except certain similarities in the process.

As a common factor, the both systems agree that the SP is a process of the combination of biological and cognitive functions. The Bio-psychological model emphasizes the biological factors of SP whereas cognitive psychologists pay much attention on cognitive process of information processing. In line with, the gestalt psychologists explains how the brain organizes the visual patterns and certain cognitive function. As same as in western psychological theories, Madupindika sutta, sabbacittasādhārana cetasika and cittavịthi in BP emphasize the importance of biological factor and cognitive factor.

Each theory or model or principle of WP explains and emphasizes one aspect of SP process; biological or cognitive. However, the Buddhist psychological explanation on SP can be seen as a combination of all these factors; affective, biological, cognitive and inner mental process. The Cittavithi analysis in BP is absolutely a psychological process and it can be considered as beyond the Western psychological theories, models and principles of SP. In conclusion, BP of SP can be identified as 'Affective-biological-cognitive model of SP'. 


\section{References}

Davids, C.A.F.R. (1914). Buddhist Psychology. London: G. Bell and sons Ltd. Extracted from https://archive.org/ details/ in.ernet.dli. 2015.247407/ page/n3.

De Silva, P. (1979). An Introduction to Buddhist Psychology (1 $1^{\text {st }}$ ed.). London: The Macmillan Press Ltd.

De Silva, P. (2014). An Introduction to Buddhist Psychology and Counselling (5 ${ }^{\text {th }}$ ed.). New York: Palgrave Macmillan.

Nārada. (1980). A Manual of Abhidhamma: Abhidhammatthasangaha (4 ${ }^{\text {th }}$ ed.). Kandy: Buddhist Publication Society.

Piyadhamma, A. (2013). The Concept of Visual Perception; A Comparative Study of Buddhist and Western Psychology, Pravacana - reviewed journal of Bhiksu University of Sri Lanka, Vol. 4 No. I - 2013, Anuradhapura: Bhiksu University of Sri Lanka.

Reed, S.K. (2004). Cognition Theory and Applications (6 ${ }^{\text {th }}$ ed.). USA: Thomson Wadsworth.

Sarathchandra, E.R. (1958). Buddhist Psychology of Perception. Colombo: The Ceylon University Press.

Tilakaratne, A. (1995). Abhidharma Adhyayana (Written in Sinhala). Colombo: Karunaratne and Sons.

Weiten, W. (2005). Psychology Themes and Variations (6 $6^{\text {th }}$ ed.). Canada: Thomson Wadsworth. 